\title{
BACTÉRIAS NA OTITE EXTERNA CANINA: ETIOLOGIA E RESISTÊNCIA
}

\author{
BACTERIA IN CANINE OTITIS EXTERNA: ETIOLOGY AND RESISTANCE
}

J. P. DOS SANTOS ${ }^{1 *}$, C. C. LOCCE ${ }^{2}$, A. FERREIRA-JÚNIOR ${ }^{1}$, S. C. BRASÃO ${ }^{3}$, E. R. BITTAR ${ }^{1}$, J. F. F. BITTAR ${ }^{1}$

\section{RESUMO}

A otite externa canina é uma doença comum e recorrente dos cães domésticos. Os objetivos deste estudo retrospectivo foram determinar as principais características (raça, faixa etária e sexo) dos cães acometidos por otite externa, as bactérias frequentemente identificadas e seus perfis de resistência a antimicrobianos. Foram utilizados dados de 148 cães atendidos no Hospital Veterinário de Uberaba entre 2009 e 2013 e diagnosticados com otite externa. 221 isolados bacterianos foram obtidos e identificados por suas características morfológicas, tintoriais e bioquímicas e testados contra onze antimicrobianos (amicacina; ampicilina; azitromicina; amoxicilina/ácido clavulânico; cefalexina; ceftiofur; ciprofloxacina; enrofloxacina; gentamicina; neomicina e tobramicina), conforme o método Kirby-Bauer. Dos 148 cães com otite externa, $51,4 \%$ (76/148) eram machos e 48,6\% (72/148) fêmeas. Os casos foram detectados principalmente nos cães com idade igual ou superior a sete anos $(54,7 \%$; $81 / 148)$. A raça Poodle foi a mais acometida $(14,84 \%$; 22/148). As bactérias mais isoladas foram Staphylococcus coagulase negativo ( $\mathrm{StCN}$ ) 33,9\% (75/221); Staphylococcus coagulase positivo (StCP) 19\% (42/221); Proteus spp. 17,2\% (38/221) e Pseudomonas aeruginosa 9,5\% (21/221). Com exceção dos antimicrobianos amicacina e ciprofloxacina, com eficácia in vitro superior a $81 \%$, as bactérias Gram negativas apresentaram resistência superior a $28 \%$ aos demais fármacos testados. 92\% das bactérias identificadas como Pseudomonas aeruginosa e 69\% dos isolados de Proteus spp. foram resistentes a neomicina. Bactérias Gram positivas apresentaram resistência superior a $32 \%$ à gentamicina, ampicilina e enrofloxacina e sensibilidade superior à $97 \%$ à amicacina e amoxicilina com ácido clavulânico. A resistência simultânea a mais de três classes de antimicrobianos foi detectada mais frequentemente em P. aeruginosa $(61,9 \% ; 13 / 21)$ e Proteus spp. $(39,47 \% ; 15 / 38)$. O tratamento de otite externa bacteriana deve ser orientado pelo isolamento do agente etiológico e teste de sensibilidade aos antimicrobianos, pois bases farmacológicas comumente encontradas em formulações otológicas, não mostraram boa eficácia in vitro.

PALAVRAS-CHAVE: ANTIMICROBIANOS. CÃES. MICRORGANISMOS. OTOPATIA.

ÁREA TEMÁTICA: Doenças infecciosas. 